\title{
From international to global: the geopolitics of disease prevention
}

\section{De internacional a global: a geopolítica da prevenção de doenças}

\author{
Vivek Neelakantan \\ Postdoctoral Research Fellow, The Indian Institute of Technology Madras. \\ vivekneelakantanster@gmail.com
}

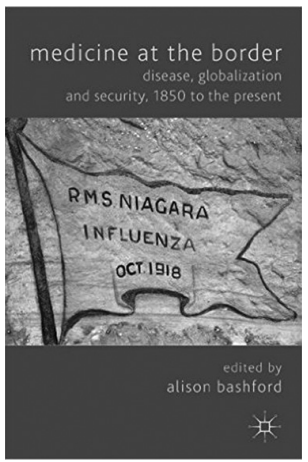

BASHFORD, Alison (Ed.). Medicine at the border: disease, globalisation and security, 1850 to the present. Basingstoke: Palgrave Macmillan. 2014. 271p.
$\mathrm{T}_{\mathrm{p}}^{\mathrm{h}}$ he publication of Medicine at the border is relevant from the perspective of how we as citizens manage our health and are managed by local, national, regional and supra-national institutions looking to preserve global safety and health. The volume collectively shows how the history of infectious disease is central to the political, legal, and commercial history of nationalism, colonialism, and internationalism. The chapters are thematically organised into three parts: (a) the connection between national history and the emergence of international health structures over the twentieth century; (b) the issue of territorial health regulation and the movement of people across national borders; and (c) contemporary global epidemiological surveillance networks that increasingly bypass the nation-state.

In a well-argued introduction, the editor, Alison Bashford, enables readers to draw connections between medicine, international relations, and human rights. Borders of many kinds, like quarantine lines, migration screening, and the home isolation of suspected virus carriers, have geopolitical implications, such as preventing disease outbreaks within sovereign states. However, the aspiration to prevent disease has resulted in pre-emptive activity that has transcended the nation-state (e.g. the European intervention in the Ottoman Empire) to prevent the spread of cholera, as attested by Patrick Zlyberman's article.

Alexandra Minna Stern's nuanced chapter explores the tight nexus between commerce, international relations, US colonialism and philanthropic public health spearheaded by the Rockefeller Foundation. Sanjoy Bhattacharya's article, based on extensive archival research at the World Health Organisation (WHO) archives, assesses the many complexities involved in the implementation of the smallpox eradication programme in India as it unfolded at the different levels of Indian administration. In their chapter, Theodore Brown, Marcos Cueto and Elizabeth Fee provide historical insights into the emergence of the terminology of global health and the role of the WHO as an agent in the transition from international to global health. 
In their comparative study of tuberculosis screening in Australia and the United Kingdom since the 1950s, Ian Convery, John Welshman and Alison Bashford outline the differences in the health screening of migrants in these two countries. Their findings indicate that whereas Australian health screening of migrants has been regulated by migration law rather than public health law, the reverse is true for the United Kingdom. Health screening for Australian visas takes place offshore in contrast to the United Kingdom, where screening of migrants and follow-up takes place at local ports.

In chapter 7, Miriam Ticktin examines the notion of medical humanitarianism operational in France since 1998, grounded in the French republican principle of universalism, which holds that all human beings are equal, offering legal permits to undocumented immigrants with life-threatening illnesses. Legal entitlements for ailing migrants in France are contingent on their continued identity as inhabiting the subject position of dependency by forgoing political rights such as the right to universal suffrage. Ailing immigrants dependent on public welfare are marked as special subjects who are unable to take care of themselves.

Renisa Mawani's chapter situates the 2002-enacted mandatory HIV/Aids testing initiative for all prospective immigrants seeking entry to Canada in the context of globalisation and national sovereignty. She argues to the effect that compulsory screening of immigrants for HIV/Aids has enabled Canada to reconstitute itself and assert its sovereignty as a nation in the era of globalisation, when national borders have become increasingly porous.

Richard Coker and Alan Ingram's contribution explores the connections between migration, security and sovereignty in order to illustrate challenges for public health. The authors suggest that the politically powerful motif of protecting domestic citizens from a threatening outside world by means of border control ultimately undermines the authority of supranational organisations such as the WHO in the implementation of a global health policy.

Chapters 10 and 12, both on Sars (Severe Acute Respiratory Syndrome), highlight the perceptions of security and risk generated by strategic and sometimes accidental coalitions of national and international agencies and global media. David Fidler's chapter explains the significance of the emergence of biosecurity as a policy issue and the new public health governance created with the advent of biosecurity. Chapter 13 contrasts the Global Public Health Intelligence Network (operational since 2003) with the earlier international health tradition (1945-1990) of sharing nationally-secured epidemiological information, as the former deploys the internet to share data rather than the geographical line of governmental border surveillance.

The essays in the volume engage in dialogue with each other and trace the historical antecedents of global health. But two points escape the attention of the contributors. First, the volume might somewhat disappoint those who seek to situate medicine in the context of cultural studies (Rosenberg, 1992). For example, the framing of a disease such as tuberculosis during the nineteenth and twentieth centuries is critical for understanding why certain diseases assumed prominence in international health. Second, the discussion in the volume pertaining to the links between globalisation, disease and management may be further enriched with reference to the 10-90 gap in global health - the statistical finding of the Global Forum for Health Research that only 10\% of global expenditure and research on health is devoted to diseases that affect the poorest $90 \%$ of the world's population. 
The social policy appertaining to healthcare is not discussed adequately in the collection. Not all the chapters in the volume examine the relationship between border security and disease. Nonetheless, the publication of Medicine at the border opens two new areas of historical inquiry that merit further research: (a) a world history of the geopolitics of disease prevention, and (b) case studies in medical history that situate the transition from international to global health.

\section{REFERENCES}

ROSENBERG, Charles.

Framing disease: illness, society, and history. In: Rosenberg, Charles; Golden, Janet (Ed.). Framing disease, studies in cultural history. Brunswick: Rutgers University. p.XIII-XXVI. 1992. 